\title{
The policy relevance of absolute and relative poverty headcounts: What's in a number?
}

\author{
Geranda Notten \\ Chris de Neubourg
}

MAASTRICHT GRADUATE SCHOOL of GOVERNANCE

\author{
Working Paper \\ MGSoG/2007/WP006
}

August 2007

Maastricht University

Maastricht Graduate School of Governance 


\section{Maastricht Graduate School of Governance}

The 'watch dog' role of the media, the impact of migration processes, health care access for children in developing countries, mitigation of the effects of Global Warming are typical examples of governance issues - issues to be tackled at the base; issues to be solved by creating and implementing effective policy.

The Maastricht Graduate School of Governance, Maastricht University, prepares students to pave the road for innovative policy developments in Europe and the world today.

Our master's and $\mathrm{PhD}$ programmes train you in analysing, monitoring and evaluating public policy in order to strengthen democratic governance in domestic and international organisations. The School carefully crafts its training activities to give national and international organisations, scholars and professionals the tools needed to harness the strengths of changing organisations and solve today's challenges, and more importantly, the ones of tomorrow.

\section{Authors}

Geranda Notten, PhD fellow

Department of Economics

Maastricht University

Email: g.notten@algec.unimaas.nl

Prof. Dr. Chris de Neubourg

Maastricht School of Governance

Maastricht University

Email: Chris.deneubourg@governance.unimaas.nl

Mailing address

Universiteit Maastricht

Maastricht Graduate School of Governance

P.O. Box 616

6200 MD Maastricht

The Netherlands

Visiting address

Kapoenstraat 2, $6211 \mathrm{KW}$ Maastricht

Phone: +31 433884650

Fax: +31 433884864

Email: info-gov@governance.unimaas.nl 


\begin{abstract}
Financial poverty indicators still play an important role in policymaking and evaluation. Countries such as the USA and the EU member states use one or several 'official' poverty indicators on which success of poverty reduction policy is regularly monitored. Whereas the US poverty indicator is based on an absolute concept of poverty, the EU Laeken indicator is based on a relative concept. But the consequences of such a decision are considerable. As absolute and relative poverty indicators reflect related but conceptually distinct approaches to determining insufficient levels of wellbeing; they can yield very different poverty statistics, particularly over time. In this paper, we use the official EU and US poverty indicators to study the policy relevance of using either an absolute or a relative indicator. We find significant differences between the poverty estimates in poverty rates as well as in the poverty profiles. Benefit incidence- and adequacy rates are equally estimated and compared. The paper concludes that the differences between the two poverty concepts is more than important enough to support monitoring poverty and the related social and economic policies, using both relative and absolute poverty indicators.
\end{abstract}

Keywords: poverty, absolute, relative, social policy, United States, European Union

JEL: H53, H55, I3 


\section{Introduction ${ }^{12}$}

This paper uses absolute and relative financial poverty lines to explore the differences between the outcomes of the two poverty headcounts and the two poverty profiles. The differences between the two and their effect on benefit incidence and benefit adequacy are important for policy analysis and policy monitoring and evaluation.

Despite critical theoretical and technical concerns expressed by many scholars, financial poverty indicators still play a very important role in policymaking and evaluation. Most countries use one or several 'official' financial poverty indicators on which progress is regularly monitored and which serve as a basis for many large scale policy interventions. The United States use an absolute poverty indicator that is based on a minimum cost of living threshold which is compared to a families' gross income. ${ }^{3}$ The financial poverty indicator as used by the EU member states is based on a relative concept of poverty; the poverty threshold is set at 60 percent of national median income and compared to household's disposable income. Every year, the annual publication of the official poverty estimates receives considerable attention in the media and public debate in all countries. The issue of financial poverty rates is hotly debated especially when poverty rates increase or when financial poverty among specific groups (e.g. children or elderly) is on the rise. Moreover, national governments use financial poverty headcounts to illustrate the success of their policies or use them as a basis for target setting in the core political arena (e.g. the UK - Blair government on child poverty). The financial poverty headcount figures are also used to guide and implement actual policy. The Orshansky poverty line in the US is for example used as a tool to determine eligibility for programmes or benefits targeted at low income families (e.g. households are eligible for food stamps if their income is below a value of $130 \%$ of the poverty line). In the EU member states the poverty

\footnotetext{
${ }^{1}$ This research benefited from a grant provided by the EuroPanel Users' Network (EPUNet) that financed a research visit to CEPS/INSTEAD (Differdange, Luxembourg) as well as from a travel grant provided by the Dutch Scientific Organization (NWO) which funded a research visit to the Kennedy School of Government (Cambridge, USA).

${ }^{2}$ We thank our colleagues at CEPS/INSTEAD (Differdange, Luxembourg), Kennedy School of Government (Cambridge, USA), National Poverty Institute (Ann Arbor, USA), Panel Study of Income Dynamics (Ann Arbor, USA) and the participants in the conference on "New Directions in the Study of Inequality" (Princeton, April 2006, USA) who have contributed to the progress of this research. We are especially grateful for the constructive suggestions of Emil Tesliuc, Christopher Jencks, Mary Jo Bane, Erzo Luttmer and Gary Sandefur.

${ }^{3}$ This indicator was developed by Molly Orshansky in the 1960s and, except for some minor changes, has merely been updated for inflation ever since.
} 
indicators are mainly used as a monitoring tool. ${ }^{4}$ However, the presence of European funds ${ }^{5}$ aimed at socially excluded groups or the development of disadvantaged regions stimulates the use of financial poverty indicators to tap into these funds by using them as solid arguments in funding proposals and project evaluations. ${ }^{6}$

Financial poverty indicators are criticized for being inadequate and out of date by many social scientists; income or expenditure based poverty estimates suffer from conceptual and measurement limitations and are believed to provide a partial and thus imperfect reflection of economic well-being. The view that this problem can be solved by using a range of indicators, each reflecting another welfare dimension, is gaining popularity. The European Union for instance, agreed on the use of a common set of indicators for the evaluation and coordination of national strategies on poverty and social inclusion in 2001. These so-called 'Laeken indicators' provide information about financial poverty, unemployment, life expectancy, health and educational attainment. However, using a range of indicators de facto implies that the list of conceptual and measurement problems only becomes longer as each indicator is suffering from similar and/or distinct problems. It is also a fallacy to think that that more information necessarily leads to improved policy decision making. The relation between policy on the one hand and indicators on the other hand is neither a direct or a straightforward one; other factors than policy influence the indicators, indicators can move in opposite directions over time while some indicators are, by construction, less responsive to policies. It can also be expected that politicians and policymakers abuse a (long) list of indicators simply by being selective and focusing on the subset of the indicators that is favourable to them. Moreover, specific indicators have a tendency to suggest specific policy solutions. Hereby, one may fail to even consider more general or multi-purpose alternatives.

\footnotetext{
${ }^{4}$ A common European social policy is very limited in scope and budget; each member state is responsible for its own social policies and may also use different poverty concepts. However, there are regular meetings between the ministers of social affairs and their employees and each member state is required to define and evaluate its targets in terms of poverty and social inclusion in National Action Plans on Social Inclusion (NAPincl) using the Laeken indicators on poverty and social inclusion (Atkinson, Cantillon, Marlier, \& Nolan, 2002; Marlier, Atkinson, Cantillon, \& Nolan, 2007). ${ }^{5}$ The European Social Fund (ESF) and the European Regional Development Fund (ERDF).

${ }^{6}$ For instance, during the second European Round Table on Poverty and Social Exclusion held in Turin on 16-17 October 2003, a workshop was organized to examine the ways in which Member States have made, or plan to make, use of Structural Funds to support measures to combat poverty and social exclusion, as identified in their National Action Plans on Social Inclusion (NAPincl) for 2003-2005.
} 
The use of a particular financial poverty indicator is often the result of a (political) debate in the past. Once chosen, it often proves difficult to switch to or incorporate another poverty indicator. Choice then becomes convention. However, by choosing either an absolute or relative poverty concept, developments in the other dimension receive less attention or are missed altogether. In the US, relative poverty indicators play no role whatsoever while out of $18 \mathrm{EU}$ Laeken indicators there is not even a single indicator reflecting the minimum cost of living in a particular country or region. Even if poverty would be considered predominantly as an absolute concept in a given society, does that mean that relative poverty can be ignored completely (or vice versa)? Is the fight against poverty and social exclusion only an issue when poverty means that persons have less than some kind of minimum living standard? Or is poverty also problematic when it means that certain groups of people have considerably less than what is considered typical or normal in a given society?

In this paper, we use the official EU and US poverty indicators to investigate potential policy implications of using either an absolute or a relative indicator. Poverty profiles based on headcount poverty statistics are key elements for the design and evaluation of (poverty alleviation) policies; they provide information about the size and characteristics of the target group and help policy makers and politicians decide about the potential scope of such policies as well as the type of policy instruments that can be used. ${ }^{7}$ Moreover, (trends in) poverty statistics are the main instrument to evaluate current and past social policies and broader economic progress. Depending on the underlying poverty concept that is chosen for the measurement of poverty, poverty statistics can lead to very different results. Using survey data for the United States and the old EU member states (EU-15) we apply the Laeken and Orshansky financial poverty indicators and find that they yield different, albeit partially overlapping, groups of poor. ${ }^{8}$ We investigate the implications of choosing either poverty concept on the size and characteristics of the target group (i.e. the poor). We also study the benefit incidence of various social benefits among the poor and non-poor both defined by an absolute and a relative poverty line. Are current social transfers successful in

\footnotetext{
${ }^{7}$ Poverty profiles also play an important role in formulating poverty reduction plans now mandatory as basis for donor financing in nearly all developing countries.

${ }^{8}$ In this paper we refer to the US official poverty indicator as the 'Orshansky' indicator and to the EU indicator as the 'Laeken' indicator (named after the place where the EU countries agreed upon the use of this common indicator).
} 
lifting people altogether out of poverty, are they beneficial predominantly at the group of 'hard core' poor (i.e. those people being poor using both indicators) or do they equally reach the 'single indicator' poor and non-poor?

We find significant differences between poverty groups defined by Orshansky and Laeken indicators in terms of size, characteristics, benefit incidence and adequacy. The differences between groups in a particular year are in some cases already substantial, but the implications of using either an absolute or relative poverty indicator over time could be substantial, especially for fast growing economies such as the new European member states. This also holds for countries with high levels of inequality. From a policy perspective, it would therefore make sense to use a poverty indicator reflecting the costs of attaining some minimum living standard as well as a poverty indicator that identifies those that have considerably fewer resources than what is considered normal or typical in a society.

The next section discusses the differences in the poverty headcount using the two poverty lines for the 16 countries under study. The impact of the choice of the poverty line on the size and the composition of the long term poor is the main issue discussed in the section thereafter. Differences between poverty profiles resulting from the absolute and the relative poverty analyses and their potential impact on social policy as well as the benefit incidence and benefit adequacy form the two larger sections before the conclusion. The appendix explains briefly the technical differences between the US Orshansky poverty count and the EU Laeken poverty estimates.

\section{More or less poverty? Orshansky and Laeken poverty in the EU and US}

Laeken and Orshansky poverty measurement methods for the United States and the old EU member states (EU-15) yield considerable differences in terms of poverty incidence (Table 1). Using disposable household income to calculate both poverty indicators, Laeken poverty is considerably higher than Orshansky poverty in the richer countries. For the Mediterranean countries the absolute (Orshansky) poverty is higher that relative (Laeken) poverty. It is not difficult to understand that higher poverty rates put the poverty problem higher on the policy agenda. It thus matters for specifying policy priorities whether countries use a relative or an absolute indicator as 
their yardstick. The success of all poverty reduction programmes, typically being judged by the reduction in the poverty headcount and the poverty gap, is consequently very sensitive for the choice of the indicator on which the poverty line is constructed. More importantly, the choice for an absolute or a relative indicator may yield very different poverty profiles, in turn leading to differences in targeting groups in policy reduction policies. In order to analyze these differences, Table 1 also calculates the overlap between the households belonging to the poor according to the Orshansky and the Laeken indicator. Looking at the estimates for $2000,88 \%$ of the poor in Spain and $83 \%$ in Italy is poor according to both indicators but the overlap is much lower for the other countries with the USA (37\%), Belgium (27\%) and Luxembourg (4\%) showing the smallest overlap.

Obviously, the first that strikes is that it matters whether one uses the US Orshansky approach or the EU Laeken approach. The degree to which poverty is considered a serious or a modest problem depends on the magnitude of the phenomenon; it makes a difference in the minds of people (including those of policymakers and politicians) whether the official poverty indicator shows that 'only' $9 \%$ of the population is poor as compared to $24 \%$ (United States). Although the USA is an extreme case, the magnitude of poverty typically doubles going from Orshansky to Laeken poverty for the richer EU member states (2000). This poverty difference does not only affect the general sense of urgency of the problem at hand but also has serious budgetary implications. The implementation of an income support programme may be financially feasible when it assists $5 \%$ of the population but may soon become problematic when a moderately larger group of people is involved. Magnitude also influences the type of policy response (for instance transfers versus tax breaks or training programmes versus changes in labour protection legislation) as well as its potential impact (considerable or negligible).

Comparing poverty in 1996 with 2000 estimates, it is also clear that Orshansky poverty is declining over time in most countries while Laeken poverty changes only moderately, albeit in either direction. This implies that according to one indicator the poverty situation in a country is improving while the other indicator may suggest no change or deterioration. Ireland is a striking example in this respect, having 
experienced a decrease in Orshansky poverty of nearly 20 percentage points and an increase in Laeken poverty of about 5 percentage points over the period 1993 to 2000.

Notten and de Neubourg (2007b) have shown the impact of the main underlying technical mechanisms determining these poverty differences. As the Orshansky poverty line is set irrespective of a countries' income distribution while the Laeken poverty line depends on national median income, distributional characteristics are a main explanatory factor. The level of income inequality below the median and changes in this inequality affect the level of absolute and relative poverty rates. In countries with higher income inequality the overlap between Laeken and Orshansky poverty is typically low(er). Furthermore, differences between absolute and relative poverty trends are more pronounced in faster growing economies. Other factors explaining poverty differences are the use of Purchasing Power Parity rates to convert the US Orshansky thresholds to national price levels and the different equivalence scales used by the EU and US poverty measurement methods. The effect of PPP conversion only influences differences between Laeken and Orshansky poverty levels but does not affect poverty trends because national inflation rates are used to update the poverty lines over time. ${ }^{9}$ Despite moderate differences in equivalence weighting schemes, the impact on the poverty estimates is considerable.

\footnotetext{
${ }^{9}$ In another paper we already indicated that the exceptional deviation of the Mediterranean countries may be related to the PPP converter that is used (Notten \& Neubourg de, 2007b). In this paper we further discuss the appropriateness of using PPP rates.
} 
Table 1: Poverty headcount (in \% of individuals, 1996 and 2000)

\begin{tabular}{|c|c|c|c|c|c|c|c|c|c|c|}
\hline & \multicolumn{5}{|c|}{1996} & \multicolumn{5}{|c|}{2000} \\
\hline & $\begin{array}{l}\text { Laeken } \\
\text { poverty }\end{array}$ & $\begin{array}{c}\text { Orshansky } \\
\text { poverty }\end{array}$ & $\begin{array}{c}\text { Overlap } \\
(\%)^{1}\end{array}$ & $\begin{array}{c}\text { Orshansky } \\
\text { OECD } \\
\text { poverty }^{2}\end{array}$ & $\begin{array}{l}\text { Overlap } \\
\qquad(\%)^{3}\end{array}$ & $\begin{array}{l}\text { Laeken } \\
\text { poverty }\end{array}$ & $\begin{array}{c}\text { Orshansky } \\
\text { poverty }\end{array}$ & $\begin{array}{c}\text { Overlap } \\
(\%)\end{array}$ & $\begin{array}{c}\text { Orshansky } \\
\text { OECD } \\
\text { poverty }\end{array}$ & $\begin{array}{c}\text { Overlap } \\
(\%)\end{array}$ \\
\hline Belgium & 14.2 & 6.1 & 43.0 & 9.5 & 66.6 & 13.3 & 3.6 & 27.0 & 6.3 & 47.2 \\
\hline Denmark & 9.3 & 3.2 & 34.1 & 5.3 & 57.3 & 10.8 & 3.4 & 31.5 & 6.4 & 59.8 \\
\hline Germany & 12.1 & 7.0 & 57.8 & 9.5 & 78.8 & 11.1 & 5.1 & 46.5 & 7.7 & 69.2 \\
\hline Greece & 21.5 & 28.1 & 76.5 & 38.5 & 55.7 & 20.5 & 26.1 & 78.5 & 35.5 & 57.9 \\
\hline Spain & 20.3 & 29.8 & 68.2 & 40.7 & 50.0 & 18.8 & 19.1 & 87.9 & 27.0 & 69.8 \\
\hline France & 14.9 & 8.8 & 58.9 & 13.1 & 87.9 & 15.4 & 6.5 & 42.3 & 10.9 & 70.6 \\
\hline Ireland & 19.1 & 20.1 & 81.1 & 28.2 & 67.8 & 21.4 & 10.6 & 49.8 & 15.5 & 72.7 \\
\hline Italy & 19.5 & 23.0 & 83.4 & 32.9 & 59.3 & 19.3 & 16.7 & 83.2 & 24.4 & 79.1 \\
\hline Luxembourg & 11.4 & 0.7 & 5.9 & 1.4 & 12.2 & 12.5 & 0.6 & 4.4 & 0.9 & 7.3 \\
\hline Netherlands & 10.5 & 6.1 & 58.6 & 9.6 & 91.5 & 11.3 & 6.6 & 58.3 & 9.9 & 88.0 \\
\hline Austria & 13.0 & 5.8 & 44.3 & 9.0 & 69.2 & 11.9 & 4.8 & 40.0 & 7.2 & 60.8 \\
\hline Portugal & 21.6 & 38.1 & 56.7 & 49.7 & 43.5 & 20.1 & 32.2 & 62.4 & 43.7 & 46.0 \\
\hline Finland & 8.3 & 4.5 & 53.8 & 6.8 & 81.7 & 11.4 & 4.9 & 43.3 & 7.2 & 62.9 \\
\hline Sweden & 8.9 & 7.1 & 76.1 & 9.3 & 96.5 & 10.4 & 5.7 & 54.9 & 6.8 & 66.0 \\
\hline United Kingdom & 17.8 & 11.4 & 64.0 & 15.5 & 87.4 & 17.1 & 9.3 & 54.6 & 12.2 & 71.7 \\
\hline United States ${ }^{4}$ & 21.9 & 8.5 & 39.0 & 10.2 & 46.6 & 23.7 & 8.8 & 37.4 & 11.0 & 46.7 \\
\hline
\end{tabular}

Note: ${ }^{1}$ Percentage of (weighted) individuals being both Laeken and Orshansky poor (compared to all poor). ${ }^{2}$ Poverty incidence using Orshansky single adult poverty and modified OECD equivalence scales (which are also used for Laeken poverty). ${ }^{3}$ Percentage of (weighted) individuals being both Laeken and Orshansky OECD poor (compared to all poor). ${ }^{4}$ For the United States there is a considerable difference between the 1996 poverty rates calculated using the individual level data or the household level data. The results displayed in this table are calculated using the household level data. Using the US individual level files, Laeken poverty is $24.6 \%$ in 1996, Orshansky poverty is $13.0 \%$ and Orshansky OECD poverty is $14.7 \%$.

Source: Own calculations ECHP and CNEF-PSID 
We have therefore also calculated the Orshansky poverty rates using the modified OECD-equivalences weights as used in the Laeken indicator (columns 4 and 8, Table 1). ${ }^{10}$ Using the same equivalence scale for both poverty indicators considerably reduces the differences between Laeken and Orshansky estimates. In 2000, the effect is particularly large for countries such as Denmark, France, Spain and the Netherlands. The Netherlands is now the country with the highest overlap (88\%). Still in many countries the overlap is below $70 \%$ and in Belgium, Portugal, United States and Luxembourg even below 50\%. The use of the same weighting scheme also reduces the heterogeneity in the characteristics of both poverty groups (Notten \& Neubourg de, 2007b). Differences between weighting schemes alter the poverty risk of demographic groups and the household types they live in. If additional children in a household have a lower weight than additional adults (as is the case in the OECD scheme) fewer children are counted as poor as compared to a scheme attributing equal weights. A weighting scheme that attributes higher economies of scale to larger households reduces the poverty risk of such households and its members. Moreover, as the share of large households in the population increases, its effect on poverty rates and risk profiles becomes larger. Given this impact of the US and OECD weighting schemes, we focus on the policy consequences of poverty differences caused by the Laeken and Orshansky poverty lines in the remainder of this paper (using the OECD modified equivalence scales to measure Laeken and Orshansky poverty). The next sections address subsequently the differences between the Orshansky method and the Laeken methodology for analysing long term poverty, poverty profiles, social benefit incidence and social benefit adequacy.

\section{Long term poverty}

Compared to other groups in society, the group of long term poor is of special concern because having low income levels for a long time not only implies the lack of an important source to finance current living standards, but also reduces investment opportunities in health, education thereby also reducing prospects of a better future

\footnotetext{
${ }^{10}$ The modified OECD equivalence scale attribute a weight of 1 to the first adult in a household, 0.5 for subsequent adults and a weight of 0.3 for children under age 14. The Orshansky scales are implicit in the sense that there are 48 poverty lines, depending on the household size and age of household members. To calculate Orshansky OECD scale poverty rates we compared the single adult poverty line with the adult equivalent income of a household.
} 
(especially when asset levels are also low). Generally, the long term poverty levels are considerably lower than annual poverty rates. But even when countries have similar poverty rates, their long-term poverty rates may differ. Take for instance Denmark, Germany, the Netherlands, Austria and Finland. The annual Laeken poverty rates in these countries are similar (10-11\%), but the long term poverty rates vary from $5.2 \%$ in Denmark to $7.1 \%$ in Austria. Or alternatively, countries with similar long term poverty rates such as Luxembourg and France (respectively $8.6 \%$ and $8.7 \%$ ) have different annual poverty rates (12.5\% and $15.4 \%)$. Exploiting the panel dimensions of the datasets we estimated long term Orshansky and Laeken poverty rates (Table 2). This indicator is also called 'at persistent risk of poverty' rate and labels individuals as long term poor if they are currently poor and also lived in poverty in at least two out of three previous years. To our knowledge, this is the first study that is providing comparable estimates of long term poverty between Europe and the United States.

Focussing on the 'at the persistent risk of poverty' according to the Laeken indicators, the countries can be distinguished in two groups: the Mediterranean countries and the USA with a high percentage of long term poor and the other European countries with a lower percentage of their population at risk of persistent poverty. The estimate for the long term poor using the Orshansky method is consistently higher than the Laeken estimate for the Mediterranean countries and Ireland and lower for the other countries. Exploring the changes between 1996 and 2000, it is clear that the changes in the relative indicator were very moderate while the Orshansky indicator showed a decline for all the countries (in some cases e.g. Ireland, spectacularly) except for Greece. It should be noted that the changes in the absolute poverty count are bigger than in the relative poverty estimate, suggesting that quite a lot of the long term poor experienced an income increase lifting them out of absolute poverty in that period but not getting them above the - for most countries - higher relative poverty line. 
Table 2: Long term poverty ${ }^{1}$ headcount (in \% of individuals, 1996 and 2000)

\begin{tabular}{|c|c|c|c|c|c|c|c|c|c|c|}
\hline & \multicolumn{5}{|c|}{1996} & \multicolumn{5}{|c|}{2000} \\
\hline & $\begin{array}{c}\text { Laeken } \\
\text { persistent } \\
\text { poverty }\end{array}$ & $\begin{array}{c}\text { Orshansky } \\
\text { persistent } \\
\text { poverty }\end{array}$ & $\begin{array}{c}\text { Overlap } \\
(\%)^{2}\end{array}$ & $\begin{array}{c}\text { Orshansky } \\
\text { persistent } \\
\text { poverty } \\
\text { OECD }^{3}\end{array}$ & $\begin{array}{c}\text { Overlap } \\
\qquad(\%)^{4}\end{array}$ & $\begin{array}{c}\text { Laeken } \\
\text { persistent } \\
\text { poverty }\end{array}$ & $\begin{array}{c}\text { Orshansky } \\
\text { persistent } \\
\text { poverty }\end{array}$ & $\begin{array}{c}\text { Overlap } \\
(\%)\end{array}$ & $\begin{array}{c}\text { Orshansky } \\
\text { persistent } \\
\text { poverty } \\
\text { OECD }\end{array}$ & $\begin{array}{c}\text { Overlap } \\
(\%)\end{array}$ \\
\hline Belgium & 8.5 & 2.8 & 32.6 & 4.4 & 51.5 & 7.4 & 1.5 & 20.8 & 3.0 & 40.8 \\
\hline Denmark & 4.2 & 0.8 & 18.0 & 1.7 & 41.0 & 5.2 & 0.7 & 12.8 & 1.7 & 33.2 \\
\hline Germany & 5.8 & 3.0 & 52.7 & 4.2 & 72.3 & 6.1 & 2.4 & 39.9 & 4.2 & 68.0 \\
\hline Greece & 13.5 & 17.9 & 74.5 & 27.4 & 49.3 & 14.2 & 19.0 & 74.6 & 28.3 & 50.1 \\
\hline Spain & 11.4 & 19.8 & 57.3 & 31.2 & 36.4 & 10.5 & 14.0 & 69.2 & 21.3 & 49.3 \\
\hline France & 8.7 & 4.3 & 48.4 & 8.0 & 87.8 & 8.7 & 2.5 & 28.7 & 6.0 & 68.3 \\
\hline Ireland & 11.8 & 16.3 & 66.8 & 24.3 & 48.6 & 13.2 & 6.7 & 50.8 & 10.7 & 80.8 \\
\hline Italy & 10.9 & 14.4 & 73.2 & 22.8 & 47.8 & 12.6 & 11.9 & 82.9 & 18.4 & 68.5 \\
\hline Luxembourg & $\mathrm{na}^{5}$ & na & na & na & na & 8.6 & 0.1 & 1.2 & 0.3 & 3.5 \\
\hline Netherlands & 5.5 & 2.8 & 50.2 & 5.2 & 91.2 & 5.3 & 2.1 & 40.4 & 4.4 & 82.0 \\
\hline Austria & na & na & na & na & na & 7.1 & 1.7 & 24.3 & 3.6 & 50.0 \\
\hline Portugal & 14.9 & 31.7 & 47.0 & 44.5 & 33.4 & 14.8 & 27.5 & 53.8 & 39.4 & 37.6 \\
\hline Finland & na & na & na & na & na & 5.9 & 2.0 & 33.4 & 3.6 & 62.0 \\
\hline Sweden & na & na & na & na & na & na & na & na & na & na \\
\hline United Kingdom & 10.3 & 6.6 & 64.0 & 9.8 & 87.6 & 10.1 & 5.0 & 49.3 & 7.4 & 72.9 \\
\hline United States & 13.8 & 5.1 & 36.9 & 6.3 & 45.8 & na & na & na & na & na \\
\hline \multicolumn{11}{|c|}{$\begin{array}{l}\text { Note: }{ }^{1} \text { Individual are long term poor or 'at persistent risk of poverty' if they are currently poor and also lived in poverty in at least two out of three previous } \\
\text { years. After the poverty status of households in a particular year has been determined, these long term poverty rates are calculated on an individual level only } \\
\text { including those individuals in the panel (with a positive longitudinal weight). }{ }^{2} \text { Percentage of (weighted) individuals being both long term Laeken and } \\
\text { Orshansky poor (compared to all long term poor). }{ }^{3} \text { Long term poverty incidence using Orshansky single adult poverty and modified OECD equivalence scales } \\
\text { (which are also used for Laeken poverty). }{ }^{4} \text { Percentage of (weighted) individuals being both long term Laeken and Orshansky OECD poor (compared to all } \\
\text { long term poor). }{ }^{5} \text { Not available or not calculated. } \\
\text { Source: Own calculations ECHP and CNEF-PSID }\end{array}$} \\
\hline
\end{tabular}


It is of course interesting to study whether the Orshansky poverty estimate would be a good proxy for the long term (at persistent risk of) poverty rate; Orshansky poverty estimates do not require panel data which at persistent risk of poverty do. It would be also interesting to know from a policy perspective to what extent there is an overlap between the poorest in any given year using an absolute poverty measure and the long term poor? A first indication is given in the columns 5 and 10 of Table 2 where it can be seen that the overlap between the two "at persistent risk of poverty" rates is only considerable for 4 countries: France, Germany, the Netherlands and the UK. However, the overlap between the Laeken "at persistent risk of poverty" rate and Orshansky "at persistent risk of poverty" rate does decline considerably over the short period between 1996 and 2000, indicating not much stability. A more direct exploration is provided in Table 3 .

Table 3: Overlap between poverty groups (in \% of individuals, 2000)

\begin{tabular}{|c|c|c|c|c|c|}
\hline & \multicolumn{2}{|c|}{$\begin{array}{c}\text { \# of poor } \\
\text { individuals }\end{array}$} & \multicolumn{3}{|c|}{2000} \\
\hline & $\begin{array}{l}\text { Cross- } \\
\text { section }\end{array}$ & Panel & Laeken poor & $\begin{array}{l}\text { Laeken poor } \\
\text { \& Orshansky } \\
\text { OECD poor }\end{array}$ & $\begin{array}{l}\text { Persistent Laeken } \\
\text { poor \& Orshansky } \\
\text { OECD poor }\end{array}$ \\
\hline & & & $\begin{array}{c}\text { (\% of } \\
\text { individuals) }\end{array}$ & $\begin{array}{l}\text { (\% of Laeken poor } \\
\text { individuals) }\end{array}$ & $\begin{array}{l}\text { (\% of Laeken poor } \\
\text { individuals) }\end{array}$ \\
\hline Ireland & 1,242 & 611 & 21.4 & 72.7 & 48.5 \\
\hline Netherlands & 1,132 & 347 & 11.3 & 88.0 & 28.5 \\
\hline Austria & 959 & 514 & 11.9 & 60.8 & 32.6 \\
\hline $\begin{array}{l}\text { United } \\
\text { Kingdom }\end{array}$ & 2,032 & 937 & 17.1 & 71.7 & 41.8 \\
\hline United States & 4,567 & $\mathrm{na}^{3}$ & 23.6 & 46.7 & na \\
\hline
\end{tabular}

Note: ${ }^{1}$ Orshansky OECD poverty incidence is calculated using Orshansky single adult poverty and modified OECD equivalence scales (which are also used for Laeken poverty). ${ }^{2}$ Percentage is based on Laeken poor individuals in the panel. Individual are long term poor or 'at persistent risk of poverty' if they are currently poor and also lived in poverty in at least two out of three previous years. ${ }^{3}$ Not available or not calculated.

Source: Own calculations ECHP and CNEF-PSID

We selected a number of 'rich' countries having various degrees of overlap between absolute and relative poverty groups; Netherlands, Ireland, Austria, United Kingdom and the United States. For these countries, the Orshansky poor are a subset of the Laeken poor (Table 3). In 2000, the percentage of Laeken poverty is high in the United States and Ireland (well above 20\%), low in the Netherlands and Austria (11$12 \%)$ and in between for the United Kingdom (17\%). The overlap between annual Laeken and Orshansky poverty groups is highest for the Netherlands (88\%) and 
lowest for the United States (47\%). In Ireland, slightly less than half of the Laeken poor (about $10 \%$ of the total population) have also been long term poor in a relative sense and are currently also poor in an absolute sense. In the other countries this group covers $42 \%$ of the Laeken poor in the UK, $33 \%$ in Austria and $29 \%$ in the Netherlands. The overlap is thus very limited and the Orshansky poverty rate cannot be regarded as a proxy for the long term poor.

The overlapping group, that is to say, the group of people that are both absolute poor and long term poor is, however, very interesting from a policy perspective; not only do these individuals currently have a very low income (insufficient to finance an acceptable minimum living standard), their income levels have been low as compared to the rest of the population over the past years as well. What are the characteristics of the people? From what sources do they derive their income? How did they end up in this situation and what do they think about their situation themselves? The limitation of this paper does not allow us to try to answer this questions but, clearly, such vulnerable groups can only be identified when poverty is measured using both relative and absolute poverty concepts.

\section{Poverty profiles}

For designing policies to have a poverty alleviating effect, both the size and characteristics of the poor (poverty profile) are relevant information. Such findings can be used to determine the type of assistance that could be provided to a target group. An increase in the social minimum pension is an obvious option if a large part of the poor are elderly people. In contrast, when working individuals and the households they live in, are a major share of the poor, other policy options such as tax breaks may be considered. When especially families with children are victim to poverty, family allowances seem to be a serious option. When absolute and relative poverty lines are very different it may well be that the poverty profiles of the two groups of poor differ as well.

To study whether this is actually the case in the EU or the USA, we compare the characteristics of the group of poor who are poor according to both indicators with group of poor who are only poor according to one of the indicators. To avoid 
unreadable tables we focus on the same subset of 'rich' countries as in Table 3; in these countries individuals are either poor regardless of whether a Laeken and Orshansky poverty indicator is used, or only poor when using the Laeken indicator. Because this means that the Orshansky poverty is consistently lower than the Laeken poverty line, this allows us again (as in Table 3), to call the (overlap) group that is poor according to both the Orshansky and the Laeken indicator, the "Orshansky- or absolute poor" and to call the persons belonging to the other (single indicator) group "relative- or Laeken-poor". We investigate differences in gender, age, household type and main source of income in 2000 and test whether the prevalence of these characteristics differs significantly between both groups using a simple Wald test (taking the specific national sampling design into account). The results are displayed in Table 4.

Except for the Netherlands, women are disproportionately more often poor than men in all countries. However, the percentage of women being poor both according to the Laeken and Orshansky poverty indicator differs significantly from the percentage of the women that is poor according to the Laeken indicator only in Austria. In that country the percentage of women being "Laeken poor" (68\%) is 10 percentage points higher than the female "Orshansky poverty "(58\%). The differences between the two groups ("Orshansky poor" and "Laeken poor") for the share of men are small and not significant. Looking at different age groups, we find significant differences between both poverty groups ("Orshansky or absolute" and "Laeken or relative") for individuals between age 25 and 49 as well as for the elderly (older then 64) in Ireland, Austria and UK. In these countries the percentage of individuals aged 25-49 is lower than average in both poverty groups, but when they are poor they are more likely to be both "absolutely poor". Older individuals in these countries, on the other hand, are more likely to be only poor when using the (relative) Laeken indicator. Note though, that their overall poverty risk may be high (Ireland and Austria) or low (UK) comparing their poverty rate with their population share. People aged 50-64 are more likely to be relatively poor in the Netherlands ("Laeken poor") rather than absolutely poor (“Orshansky poor”).

When looking at the type of living arrangements, significant differences between the "Orshansky poor" and the "Laeken poor" are very different according to the country 
that we study. In the United States, we find significant differences for nearly all types of living arrangements (with significantly higher "absolute poor" among the single adult families and the "other households with children" and lower rates of absolute poor among two-adults families with and without children), while none of the differences between household groups is significant in the UK. Single adults are more likely to be found in the "Orshansky poverty" group in Ireland, contrary to Austria, where they are more likely to appear in the "Laeken poverty" group.

When dividing the population according to their main income source, a more general pattern appears across countries. In the overlapping Laeken and Orshansky poverty group (the "absolute poor"), the share of individuals living in households where either social assistance, unemployment benefits or other benefits are the main source of income, is larger than among the "relative poor". On the other hand, individuals living in households with employment related earnings as the main income source are more likely to be present in the "Laeken poor" group in Austria, the Netherlands and the USA. In Ireland and the UK, old age pensions seem to play an important role lifting people above the (lower) Orshansky poverty line but disproportionately less often above the (higher) Laeken poverty line. It is remarkable that individuals living in households where private income is the main source of income are found to be more often in the absolute poor category than in the group of relative poor, although their poverty is much smaller than that of any other income-source group: it seems that most people living on private income are doing very well but those and are not likely to belong to lowest income category.

What is to be learned from this analysis of the differences in the poverty profiles between an analysis based on an absolute (Orshansky) poverty line and one that is based on a relative (Laeken) poverty line? Assuming that we would use the poverty profile only for targeting social policy (and implicitly assume that we would like to target social policy), we can now see which groups in which countries would get more or less attention according to the poverty measurement method that is used. The first conclusion, however, should be that, for targeting purposes the choice of the poverty indicator does not seem to matter terribly for a large number of groups, especially in the Netherlands and the UK where we found a small number of significant differences between the two estimates in this respect. There are, however, differences that would 
lead to very different policy options depending on whether we base the poverty profile of a country on a relative or an absolute poverty estimate. Adopting the lower absolute headcount would lead to relatively more attention to:

in the Netherlands:

- other households with children and

- individuals living in a household with "other benefits" as the main income source

in Ireland:

- individuals aged $25-49$

- $\quad$ single person households and

- people living on an unemployment benefit;

in Austria:

- individuals aged $25-49$ and

- two adult households;

in the UK:

- individuals aged $25-49$

- people living on an unemployment benefit and

- people living on other benefits (largely social assistance);

in the USA:

- single adult household

- other families with children

- people with a social benefit as the main source of income.

If we would use a relative poverty measure in the five countries we would target our policies more towards the following groups:

in the Netherlands:

- individuals aged $50-64$ and

- wage earners;

in Ireland:

- the elderly $(>65)$

- two adult households without children and

- pensioners;

in Austria:

- women

- the elderly 
- single adult families and

- wage earners;

in the UK:

- pensioners;

in the USA:

- two adult families

- tow adult families with children and

- wage earners.

As already remarked and accounted for in more detail in Notten and de Neubourg (2007a), there is, however, a considerable degree of consistency in identifying the groups in the economy that are hardest hit by poverty between estimates based on a absolute and a relative poverty definition. For many of the breakdowns the choice of the poverty measurement method would have no influence on the group that experienced the highest poverty rate.

Nevertheless, we find that in quite some cases the poverty risk for a particular group is more or less pronounced when using either a Laeken or an Orshansky poverty line. The pension system seems to be another underlying factor contributing in many inconsistencies in poverty risk; inconsistencies between both poverty indicators occur more often with elderly age groups and households whose main source of income is a pension. It should, also, not be forgotten that absolute and relative poverty lines show diverging developments over time and that the resulting poverty trends may thus be opposing or diverging. Over a decade, the underlying composition of both poverty groups may change considerably, especially in fast growing economies or countries experiencing substantial social and demographic changes or structural reforms. For these cases it still would matter a lot whether a relative or an absolute poverty line is chosen as a basis for targeting social and economic policy. 
Table 4: Population and poverty profile (in \% of individuals, 2000)

\begin{tabular}{|c|c|c|c|c|c|c|c|c|c|c|c|c|c|c|c|}
\hline & \multicolumn{3}{|c|}{ Netherlands } & \multicolumn{3}{|c|}{ Ireland } & \multicolumn{3}{|c|}{ Austria } & \multicolumn{3}{|c|}{ United Kingdom } & \multicolumn{3}{|c|}{ United States } \\
\hline & All ${ }^{1}$ & $\mathbf{O}^{2}$ & $\mathbf{L}^{34}$ & All & $\mathbf{O}$ & $\mathbf{L}$ & All & $\mathbf{O}$ & $\mathbf{L}$ & All & $\mathbf{O}$ & $\mathbf{L}$ & All & $\mathbf{O}$ & $\mathbf{L}$ \\
\hline \multicolumn{16}{|l|}{ By: Gender } \\
\hline - Female & 50.4 & 49.4 & 43.7 & 50.7 & 54.1 & 53.7 & 51.6 & 58.8 & $68.3^{05}$ & 52.4 & 58.2 & 57.4 & 51.8 & 54.5 & 54.5 \\
\hline - Male & 49.6 & 50.6 & 56.3 & 49.3 & 45.9 & 46.3 & 48.4 & 41.2 & 31.7 & 47.6 & 41.8 & 42.6 & 47.8 & 45.0 & 45.0 \\
\hline \multicolumn{16}{|l|}{ By: Age groups } \\
\hline$-0-15$ & 20.1 & 29.5 & 26.4 & 23.4 & 28.0 & 28.9 & 18.5 & 19.6 & 20.1 & 19.8 & 28.6 & 24.1 & 23.3 & 33.7 & 31.0 \\
\hline$-16-24$ & 10.7 & 21.6 & 18.9 & 15.5 & 9.3 & 8.4 & 10.4 & 10.2 & 8.1 & 10.0 & 12.3 & 9.6 & 12.2 & 16.2 & 14.2 \\
\hline$-25-49$ & 38.6 & 34.3 & 34.9 & 35.6 & 31.0 & $24.1^{05}$ & 38.5 & 29.6 & $23.0^{10}$ & 33.7 & 25.3 & $19.6^{01}$ & 37.0 & 29.5 & 32.6 \\
\hline$-50-64$ & 17.6 & 9.9 & $16.0^{10}$ & 14.3 & 11.4 & 8.9 & 17.4 & 14.3 & 12.7 & 18.5 & 11.7 & 12.2 & 15.6 & 8.4 & 9.5 \\
\hline - Above 65 & 13.0 & 4.7 & 3.8 & 11.0 & 20.3 & $29.7^{10}$ & 15.2 & 26.2 & $36.1^{05}$ & 18.0 & 11.5 & $12.1^{01}$ & 11.5 & 22.0 & 34.6 \\
\hline \multicolumn{16}{|l|}{ By: Household type } \\
\hline - Single adult & 15.6 & 17.2 & 13.7 & 7.3 & 24.1 & $7.5^{01}$ & 12.8 & 18.5 & $33.5^{01}$ & 13.2 & 22.8 & 21.6 & 13.3 & 17.3 & $14.2^{10}$ \\
\hline - Two adults & 28.6 & 10.3 & 12.5 & 10.1 & 7.2 & $24.7^{01}$ & 17.2 & 23.8 & $11.0^{01}$ & 27.2 & 18.3 & 22.0 & 22.4 & 9.2 & $13.6^{01}$ \\
\hline - Other adult households & 8.3 & 5.9 & 13.7 & 14.9 & 4.3 & 8.1 & 16.5 & 11.5 & 6.3 & 11.7 & 3.6 & 3.9 & 8.1 & 3.9 & 4.3 \\
\hline - Two adults and children & 27.9 & 23.0 & 34.0 & 19.3 & 16.6 & 10.7 & 24.0 & 12.4 & 16.8 & 23.9 & 14.1 & 16.0 & 23.6 & 12.9 & $20.3^{01}$ \\
\hline $\begin{array}{l}\text { - Other households with } \\
\text { children }\end{array}$ & 19.7 & 43.5 & $26.2^{10}$ & 48.4 & 47.8 & 49.0 & 29.5 & 33.8 & 32.4 & 24.0 & 41.2 & 36.4 & 32.6 & 56.8 & $47.6^{01}$ \\
\hline \multicolumn{16}{|l|}{ By: Main income source ${ }^{5}$} \\
\hline -Wage & 70.3 & 47.2 & $63.9^{10}$ & 67.8 & 32.0 & 40.4 & 70.9 & 21.7 & $37.2^{05}$ & 61.1 & 26.1 & 33.9 & 821 & 520 & $701^{01}$ \\
\hline - Self-Employment & 3.1 & 2.1 & 4.5 & 11.6 & 4.9 & 7.5 & 6.6 & 14.5 & 10.4 & 6.2 & 2.5 & 1.1 & 82.1 & 52.9 & \\
\hline - Pensions & 15.9 & 6.8 & 8.2 & 10.2 & 21.4 & $33.3^{10}$ & 17.4 & 35.3 & 40.1 & 19.0 & 24.3 & $38.2^{01}$ & 11.3 & 17.1 & 17.0 \\
\hline - Unemployment benefits & 0.7 & 0.9 & 1.2 & 3.2 & 14.4 & $3.8^{10}$ & 0.5 & 3.8 & $0.9^{10}$ & 0.4 & 2.5 & $0^{05}$ & & & 01 \\
\hline - Other benefits & 9.1 & 38.8 & $21.0^{05}$ & 6.6 & 25.9 & 15.0 & 3.5 & 16.4 & 10.5 & 11.3 & 39.8 & $26.0^{01}$ & 2.8 & 21.3 & $2.3^{01}$ \\
\hline - Private income & 1.0 & 4.3 & $1.2^{10}$ & 0.7 & 1.6 & $0.1^{05}$ & 1.0 & 8.3 & $0.9^{01}$ & 2.1 & 4.8 & $0.9^{01}$ & 3.9 & 8.8 & $1.6^{01}$ \\
\hline
\end{tabular}

Notes: ${ }^{1}$ All = population. ${ }^{2} \mathrm{O}=$ Laeken and Orshansky OECD poor (using same equivalence scales). ${ }^{3} \mathrm{~L}=$ Laeken poor but not Orshansky OECD poor (using same equivalence scales). ${ }^{4}$ Also indicated in this column: Wald test on difference in between means of 'O' and 'L' poverty groups (taking sample design into account). Only the following significance levels are indicated: $1 \%\left({ }^{01}\right), 5 \%\left({ }^{05}\right)$ and $10 \%\left({ }^{10}\right) .{ }^{5}$ Indicates the $\%$ of individuals living in a household where such earnings form the main source of income.

Source: Own calculations ECHP and CNEF-PSID 


\section{Social transfer incidence and adequacy}

The tax and social transfer systems in Europe and the USA are complex systems that redistribute funds from rich to poor, from working age adults to the young and the elderly and from workers to non-workers. In doing so, they affect the shape of the (disposable) income distribution and thus also influence absolute and relative poverty rates. If one excludes social transfers from household income, Laeken poverty rates would be $35 \%$ in the Netherlands and Ireland, 38\% in Austria, 39\% in the United Kingdom and $33 \%$ in the United States. Orshansky poverty would be somewhat lower varying from $32 \%$ in the United Kingdom to $19 \%$ in the United States (Notten \& Neubourg de, 2007a). ${ }^{11}$ These numbers reflect the joint impact of the complete social transfer system. The data and the estimates we have made allow us to study the impact of transfers separately. Whether social transfers are targeted at low income groups and whether a particular type of transfer contributes to lifting people out of absolute (Orshansky) poverty but not out of relative (Laeken) poverty or is it successful in terms of both indicators, are questions that will be addressed in the rest of this section.

Table 5: Incidence of social transfers ${ }^{1}$ (in \% of individuals, 2000)

\begin{tabular}{|c|c|c|c|c|c|}
\hline & \multicolumn{5}{|c|}{ Incidence by benefit category } \\
\hline & $\begin{array}{c}\text { Old age } \\
\text { Pensions }\end{array}$ & $\begin{array}{c}\text { Family } \\
\text { allowance }\end{array}$ & $\begin{array}{l}\text { Other social } \\
\text { insurance }^{3}\end{array}$ & $\begin{array}{c}\text { Social } \\
\text { assistance }\end{array}$ & $\begin{array}{c}\text { Other } \\
\text { benefits }\end{array}$ \\
\hline Netherlands & 18.7 & 46.7 & 13.2 & 3.5 & 8.5 \\
\hline Ireland & 23.6 & 65.4 & 30.6 & 14.3 & 7.3 \\
\hline Austria & 35.5 & 58.4 & 18.1 & 0.6 & 9.1 \\
\hline United & 29.1 & 47.6 & 18.4 & $\mathrm{na}^{6}$ & 15.0 \\
\hline Kingdom & & & & & \\
\hline United States $^{5}$ & 22.7 & & & & \\
\hline
\end{tabular}

Note: ${ }^{1}$ The incidence rate represents the $\%$ of individuals living in households receiving income from a particular benefit category. ${ }^{2}$ Pensions include social and private pensions. ${ }^{3}$ Other social insurance includes unemployment and sickness/disability benefits. ${ }^{4}$ Other benefits include education, housing and other allowances. ${ }^{5}$ For the United States we can only distinguish between pensions and other social transfers. ${ }^{6}$ Not available or not calculated.

Source: Own calculations ECHP and CNEF-PSID

We evaluate how various types of social transfers affect the poor and non-poor population, again dividing the poor population into the absolute (Orshansky) poor and the relative (Laeken) poor and contrast the presence of social transfers for these groups with transfers to non-poor population. More specifically, we investigate to

\footnotetext{
${ }^{11}$ Orshansky poverty rates calculated using the United States implied equivalence scales.
} 
what extent both poverty groups are covered by the social transfer system by looking at incidence rates (whether a person is actually receiving social transfers) and mean value (adequacy of social transfers). We examine three ${ }^{12}$ types of transfers: old age pensions (private and public), family allowances and social assistance. For the United States we have only two transfer types; pensions (social security pensions ${ }^{13}$ and private retirement income) and other social transfers (including temporary assistance to needy families and food stamps).

Table 5 lists the benefit incidence of five social transfer categories in the same five countries that we studied in the previous sections. The incidence rates reflect the percentage of individuals living in households that reported receiving a particular benefit. Although pensions, family allowances and other social insurance benefits are common transfers in all countries, the incidence of these transfers clearly differs by country. The incidence of pensions varies from 23\% in the US to $36 \%$ in Austria, while family benefits have the highest incidence rates in the European countries varying from $47 \%$ in the Netherlands to $65 \%$ in Ireland. The lower incidence of nonpension social transfers in the United States can partly be explained by the fact that we ignore 'transfers' through the tax system such as tax breaks and tax credits. ${ }^{14}$ Difference between the countries is not always a reflection of differences in policies but can also be influenced by basic demographic and economic differences: e.g. the incidence of old age pensions is clearly related to the share of elderly in the economy.

The classification of the transfer categories suggests which type of risk is being covered; old age pensions cover the risk of no or low income at old age while other social insurance transfers insure the retention of some income in the event of illness, disability or unemployment. Family allowances financially support parents with the upbringing of their children and social assistance helps households that have no or a very low income. This, however, does not mean that the prevention of that risk is the

\footnotetext{
${ }^{12}$ Except for the figures in Table 5 and Table 6, we do report the results for two other types of benefits that we studied - other social insurance benefits (unemployment, sickness and disability) and other benefits (housing allowance, education allowance and other stipends). The differences found were not very big or different from what we found for the three others.

${ }^{13}$ Social security pensions include public old age, survivor and disability pensions.

${ }^{14}$ Although our estimates of US disposable income incorporate the value of such tax 'transfers', the data do not allow us to analyze them separately. This implies that we cannot identify their presence or mean value.
} 
sole motive or that the transfer is successful in achieving its objective. The degree to which such transfers are targeted at those individuals that really need such support, differs by transfer category and by country. Some transfers are targeted at specific demographic groups while other transfers (additionally) require an income or means test. Moreover, the generosity of each type of transfer varies, as does its resulting impact on the level of economic well-being of the individual and its household. In this paper we focus on evaluating the impact of these transfers on the partially overlapping absolute and relative poverty groups as compared to the rest of the population. This may, or may not, correspond with the actual objectives of these policies in the studied countries. Table 6 shows a decomposition of the benefit incidence for 3 different groups: the "absolute (Orshansky) poor", the "relative (Laeken) poor"15 and the nonpoor in 2000. A first observation is that incidence levels vary considerably between these population groups but not necessarily systematically across countries. We discuss each transfer category in turn (patterns in "other social transfers" in the United States are discussed under social assistance benefits).

\section{Pensions}

In the Netherlands, receipt of old age pensions in both poverty groups is significantly lower than for the non-poor group. In Ireland and the United Kingdom, pension incidence in the Laeken and Orshansky poverty group is similar to that in the nonpoor group while it is much higher in the Laeken only group. There are no significant differences between the population groups in the United States while in Austria the pension incidence is higher in both poverty groups. Thus, depending on the country, receipt of pensions is associated with a lower poverty risk (Netherlands), an increased poverty risk (Austria), with a higher risk for those in relative - Laeken only - poverty (Ireland and United Kingdom) or an average poverty risk (United States).

\footnotetext{
${ }^{15}$ As in the former sections, "absolute or Orshansky poor or poverty" refer in the case of the countries under study in this section to the people that are poor according to both the Orshansky and the Laeken poverty line; "relative of Laeken poor or poverty" refers to the group of individuals that are poor according to the Laeken indicator only; they are the group between the 2 poverty lines as used in the figures; this all holds because for the 5 countries that we study, the persons poor according to the Orshansky poverty line is a subset of the group of people that is poor according to the Laeken indicator.
} 
Table 6: Incidence of social transfers ${ }^{1}$ for different population groups (in \% of individuals, 2000)

\begin{tabular}{|c|c|c|c|c|c|c|c|c|c|c|c|c|c|c|c|}
\hline & \multicolumn{3}{|c|}{ Old age pensions ${ }^{2}$} & \multicolumn{3}{|c|}{ Family allowance } & \multicolumn{3}{|c|}{ Other social insurance $^{3}$} & \multicolumn{3}{|c|}{ Social assistance } & \multicolumn{3}{|c|}{ Other benefits ${ }^{4}$} \\
\hline & $\mathbf{O}^{5}$ & $\mathrm{~L}^{6}$ & $\mathbf{N P}^{7}$ & $\mathbf{O}$ & $\mathbf{L}$ & NP & $\mathbf{O}$ & $\mathbf{L}$ & NP & $\mathbf{O}$ & $\mathbf{L}$ & NP & $\mathbf{O}$ & $\mathbf{L}$ & NP \\
\hline Netherlands & 7.5 & 8.2 & 20.2 & 57.2 & 65.5 & 45.3 & 18.2 & 12.0 & 12.7 & 14.1 & 11.4 & 2.2 & 16.4 & 19.6 & 7.5 \\
\hline Wald test: $\mathrm{O} \hat{\mathrm{U}} \mathrm{L}^{8}$ & & ns & & & ns & & & $\mathrm{ns}$ & & & $\mathrm{ns}$ & & & ns & \\
\hline L Û NP & & .01 & & & .01 & & & ns & & & .10 & & & .10 & \\
\hline $\mathrm{O} \hat{U} \mathrm{NP}$ & & .01 & & & .01 & & & .10 & & & .01 & & & .01 & \\
\hline Ireland & 23.3 & 43.4 & 22.2 & 61.4 & 59.1 & 66.7 & 40.3 & 35.5 & 28.3 & 42.4 & 34.0 & 7.3 & 6.1 & 4.0 & 9.4 \\
\hline Wald test: $\mathrm{O}$ Û $\mathrm{L}$ & & .01 & & & $\mathrm{~ns}$ & & & $\mathrm{~ns}$ & & & $\mathrm{~ns}$ & & & ns & \\
\hline LÛ NP & & .01 & & & ns & & & $\mathrm{ns}$ & & & .01 & & & ns & \\
\hline OÛ NP & & ns & & & $\mathrm{ns}$ & & & .05 & & & .01 & & & .01 & \\
\hline Austria & 44.7 & 51.9 & 33.8 & 56.0 & 58.1 & 58.7 & 14.2 & 21.2 & 18.2 & 2.1 & 2.0 & 0.4 & 7.6 & 13.0 & 9.6 \\
\hline Wald test: $\mathrm{O} \hat{\mathrm{U}} \mathrm{L}$ & & $\mathrm{ns}$ & & & ns & & & ns & & & $\mathrm{ns}$ & & & $\mathrm{ns}$ & \\
\hline L Û NP & & .01 & & & ns & & & $\mathrm{ns}$ & & & $\mathrm{ns}$ & & & ns & \\
\hline $\mathrm{OUU} \mathrm{NP}$ & & .05 & & & ns & & & ns & & & .10 & & & $\mathrm{~ns}$ & \\
\hline United Kingdom & 28.0 & 41.6 & 28.6 & 53.8 & 52.0 & 46.5 & 25.6 & 21.3 & 17.2 & $\mathrm{na}^{10}$ & na & na & 36.4 & 33.2 & 16.9 \\
\hline Wald test: $\mathrm{O} \hat{\mathrm{U}} \mathrm{L}$ & & .01 & & & $\mathrm{~ns}$ & & & ns & & & . & & & $\mathrm{ns}$ & \\
\hline L Û NP & & .01 & & & ns & & & ns & & & . & & & .01 & \\
\hline OÛ NP & & ns & & & .01 & & & .01 & & & . & & & .01 & \\
\hline United States 9 & 22.1 & 25.0 & 22.4 & & 45. & & & & 24.5 & & & & 7.4 & & \\
\hline Wald test: $\mathrm{O} \hat{\mathrm{U}} \mathrm{L}$ & & ns & & & & & & & & & & & & & \\
\hline LÛ NP & & ns & & & & & & & & & & & & & \\
\hline OU NP & & ns & & & & & & & & & & & & & \\
\hline
\end{tabular}

Notes: ${ }^{1}$ The incidence rate represents the $\%$ of individuals living in households receiving income from a particular benefit category. ${ }^{2}$ Pensions include social and private pensions. ${ }^{3}$ Other social insurance includes unemployment and sickness/disability benefits. ${ }^{4}$ Other benefits include education, housing and other allowances. ${ }^{5} \mathrm{O}=\mathrm{Laeken}$ and Orshansky poor (using same equivalence scales). ${ }^{6} \mathrm{~L}=$ Laeken poor but not Orshansky poor (using same equivalence scales). ${ }^{7} \mathrm{NP}=\mathrm{Not}$ poor. ${ }^{8} \mathrm{Wald}$ test on difference between means of population groups (taking sample design into account). Indicated significance levels: $1 \%(.01), 5 \%$ (.05), 10\% (.10) and not significant (ns). ${ }^{9}$ For the United States we can only distinguish between pensions and other social transfers. ${ }^{10}$ Not available or not calculated.

Source: Own calculations ECHP and CNEF-PSID 
Figure 1: Incidence of pensions (below median income, 2000)
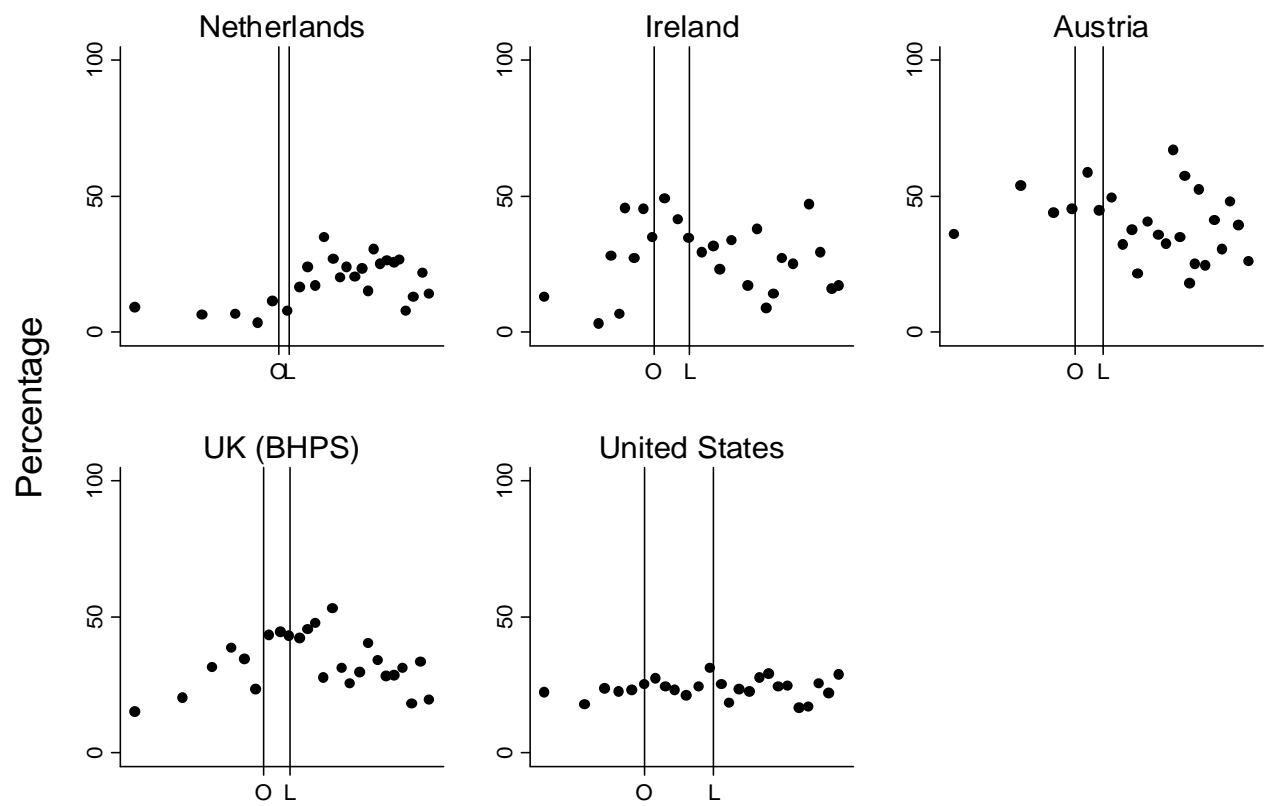

Equivalent income

Figure 2: Mean value of pension (below median income, 2000)
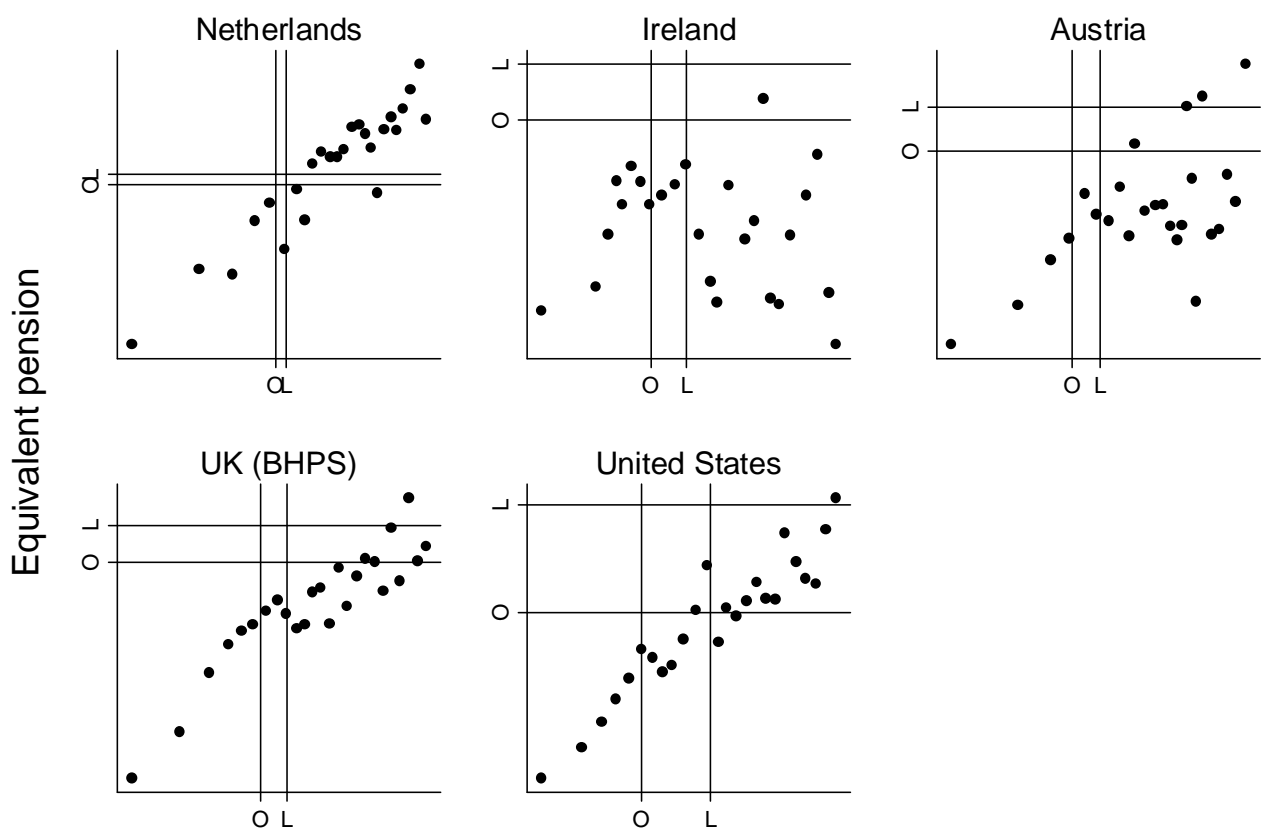

Equivalent income

Note: The figures include only observations below median income and all values are expressed in equivalent adult values (thus $50 \%$ of the total sample). Each dot represents the mean incidence or value (only including positive observations) of adult equivalent pension received by $2 \%$ of the sample. The horizontal and vertical lines represent the adult equivalent Laeken (L) and Orshansky (O) poverty lines. Source: Own calculations ECHP and CNEF-PSID 
Pensions systems are complex systems that are designed to help individuals with smoothing their income over the life cycle. Although the prevention of poverty at old age has certainly been an important motive for the development of pension systems, benefits depend for a large part on the contribution history of the individual in a lot of countries. Persons with a long contribution record and/or high income during working life have acquired more pension rights and are thus receiving a higher pension. Another factor influencing incidence patterns is that pension recipients may be part of a household that also includes non-elderly persons. The indicator of pension incidence used in this paper counts all individuals living in the household receiving a pension, not just those individuals that are eligible. Even though an elderly person's pension may be sufficient to lift that person out of poverty, the pension and other income sources may fall short when all individuals of the household are taken into account (or vice versa). These explanations are consistent with the distributional patterns observed in Figure 1 and Figure 2. The figures plot the mean incidence and value of pensions received against the mean income of the receiving individuals in 2000. Each dot represents $2 \%$ of the total population. The figures include only observations below median income and all values are expressed in equivalent adult values. The horizontal and vertical lines represent the locus of the Laeken (L) and Orshansky (O) poverty lines. Individuals with an equivalent income below and left of the poverty lines are living in absolute and/or relative poverty.

Figure 1 shows that the incidence of benefits across the income distribution is approximately linear in the US but non-linear in the other countries. Interestingly, in the Netherlands and United Kingdom, incidence rates peak beyond the relative poverty lines. In Austria and Ireland the highest incidence rates are covering the area of the Laeken and Orshansky poverty lines. By determining who is eligible for how much benefit, social transfer systems also exercise influence on the prevalence of particular individual and household level characteristics along the income distribution. For instance, the peaks in pension incidence also provide some information about the characteristics of the individuals in that area of the income distribution; a high incidence of pension benefits typically also indicates a higher prevalence of elderly persons. In the Netherlands, the 
share of elderly persons in both poverty groups is well below their average population share (Table 4). However, it need not be the case that high rates of pension incidence beyond the poverty line also imply that elderly persons also have a lower than average poverty risk. Take for instance the US, where there are no significant differences in the incidence of pensions across the income distribution and where the age group 65 and above comprises $12 \%$ of the total population; the population shares of the poor pension aged individuals are well above their average population share (22\% for the "Orshansky poverty group" and 35\% for the "Laeken poverty group"). Figure 2 offers an explanation as the mean value of pensions received in the US lies well below the Orshansky and, in quite some cases, also below the Laeken poverty line.

The pattern of pension transfers is proportional in all countries; as equivalent income increases, the mean equivalent value of pensions rises as well. The relation is strong in the Netherlands, United Kingdom and United States, somewhat weaker in Austria and rather weak in Ireland. The pension systems in all these countries have multiple pillars; there is a first pillar reflecting a minimum or basic pension while the second and third pillars reflect contributions-related benefits (International Social Security Association, 2002 , 2003). The minimum pension is means or income tested in most countries, except in the Netherlands where a basic pension is provided to every citizen. Despite the limitations discussed above, the figures provide an impression of the poverty reduction impact of these (minimum) pensions. In the Netherlands, most of the dots in Figure 2 lie to the right and above the absolute and relative poverty lines, implying that the mean value of pension received is sufficient to lift an equivalent adult out of poverty. This is much less the case in the other countries. Even though quite a number of dots lie to the right of the vertical Orshansky poverty line, most of those dots lie under the horizontal Orshansky poverty line (Austria, Ireland and the UK); although these individuals have sufficient income to lift themselves out of absolute poverty, pensions play only a partial role in achieving this outcome. As income levels increase, pensions in the US clearly contribute to achieving above Orshansky poverty line income levels but not sufficiently to reach an income above the Laeken poverty line. 
What are the possible scenarios when pension transfers are inadequate in order to finance a given living standard? In some cases, pensioners may have accumulated sufficient other assets over their lifetime to finance current consumption. For instance, when pensioners live in their own house with no need for mortgage payments (the disposable income indicator does not include imputations for consumption owned housing). As they do not have to pay rent, such pensioners may be counted as poor while their actual living standard may be above the poverty line. However, when low pensions are the result of a short contribution history combined with a low minimum pension, recipients most likely do not own large reserves of assets. As the opportunities of paid work are decreasing with old age, the main alternative to a life in poverty for these pensioners would be to move in with relatives. Looking at the incidence and mean value patterns in the figures, this option may explain the patterns in Austria and Ireland where a considerable subgroup of non poor is having rather low average pensions. Is it acceptable that (means or income tested) minimum pensions are not sufficient to cover a minimum acceptable living standard? Or is it problematic when pensioners are more likely to be (only) relatively poor? The answer to such questions remains the responsibility of the political arena and ultimately their electorate. However, having official poverty indicators reflecting both dimensions may be very useful in such a discussion. 
Figure 3: Incidence of family allowances (below median income, 2000)
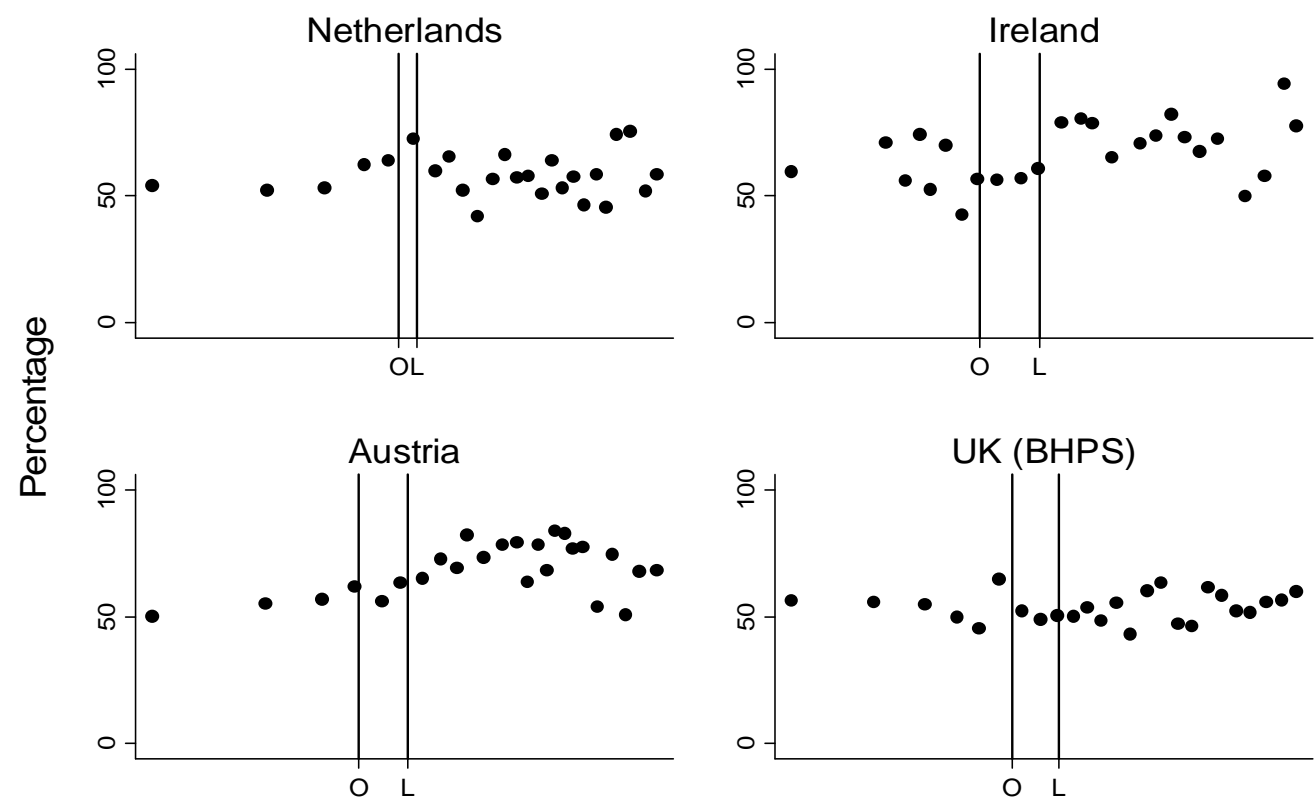

Equivalent income

Figure 4: Mean value of family allowances (below median income, 2000)
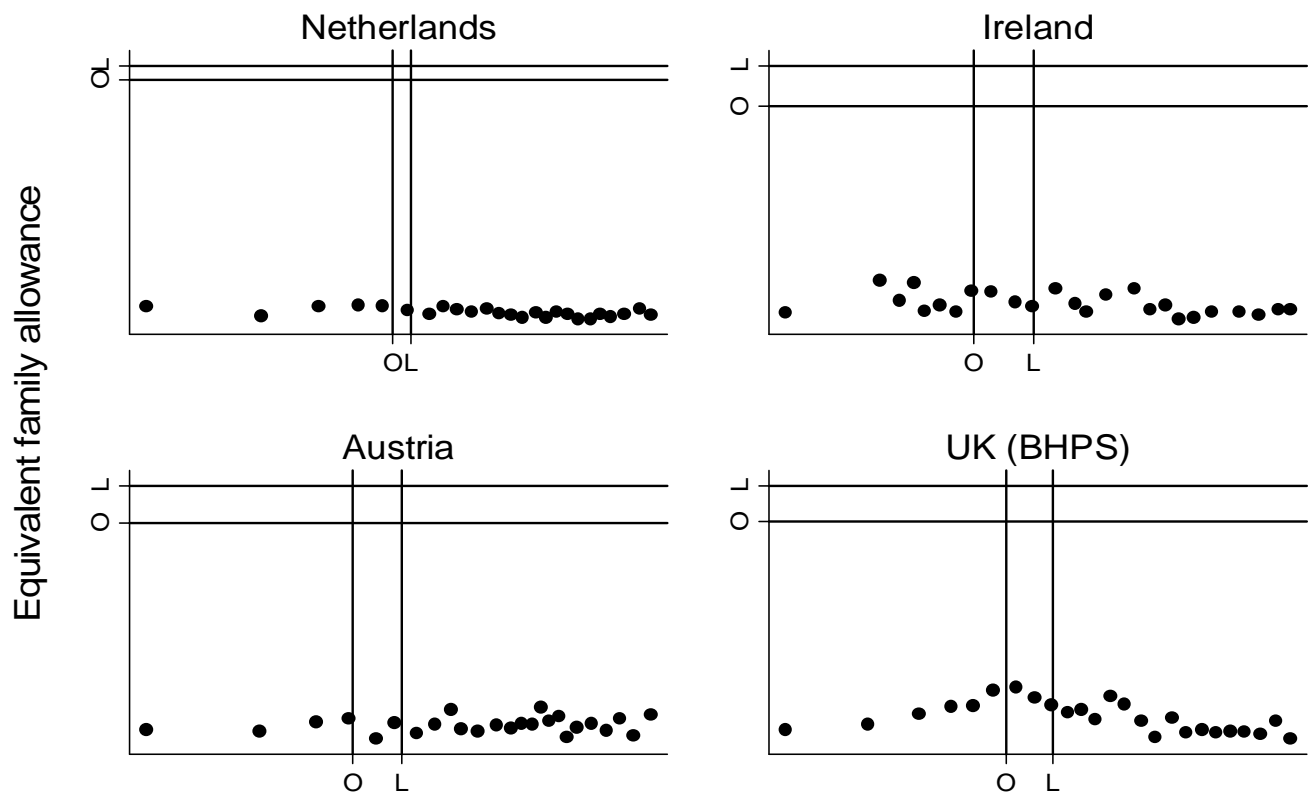

Equivalent income

Note: The figures include only observations below median income and all values are expressed in equivalent adult values (thus 50\% of the total sample). Each dot represents the mean incidence or value (only including positive observations) of adult equivalent family allowances received by $2 \%$ of the sample. The horizontal and vertical lines represent the adult equivalent Laeken $(\mathrm{L})$ and Orshansky $(\mathrm{O})$ poverty lines.

Source: Own calculations ECHP and CNEF-PSID 


\section{Family allowances}

The incidence of family allowances is very high in the four European countries that we consider. While there are some significant difference between either of the poverty groups and the non poor population (Netherlands and UK); there are no significant differences between the incidence rates both poverty groups. Figure 3 and Figure 4 indeed show that benefit incidence is rather constant across income levels, although some local 'peaks' can be identified. The pattern is also relatively constant in terms of mean benefit value. Clearly, benefit levels are well below the adult equivalent level and one third of this level (the equivalence weight of a child under age 14). The mean values of family allowance received seem to be somewhat higher at income levels in the middle of the figures as compared to very low and 'near' median incomes; this is especially clear in the case of the United Kingdom. These peaks may indicate a higher presence of households with one or more children. Family allowances in each of these countries are universal and vary by country as well as by the number of dependent children (International Social Security Association, 2002). Only in Ireland low income families and single parents are eligible for an additional income tested allowance. In the UK there is an income depended tax credit (the value of this credit is not included in the mean transfer amounts). The prevention of child poverty, either in an absolute or relative sense, is not the main objective of these allowances.

\section{Social assistance benefits}

Social assistance benefits are typically provided to low income households. Often an income or means test is accompanied by other criteria (i.e. having children, job search or willingness to work). ${ }^{16}$ We include the 'Other social transfer category' from the US under this heading as two of the main low income support programmes are included in these transfers (food stamps and temporary assistance to needy families). In some countries such assistance is limited to a certain time period (US) while in other benefits may be

\footnotetext{
${ }^{16}$ For details about the European systems of social assistance see de Neubourg et al. (2007).
} 
received over a prolonged period (Netherlands). ${ }^{17}$ Incidence levels vary considerably between countries ranging from $42-46 \%$ of the Laeken and Orshansky poor individuals in Ireland and the US to $2 \%$ in the same poverty group in Austria. In the European countries significant differences in incidence levels can only be found between the poor and non poor population groups while in the US the benefit incidence level vary significantly between all population groups. These patterns are confirmed in the distributional plots; especially in Ireland and the US incidence levels show a steep decline as income levels increase. Such patterns correspond to slow phasing out of income support, in order to prevent the creation of a poverty trap. However, the plots of mean benefit values show that the level of benefits does not vary greatly by income levels. If a phasing out of benefit would be applied, it can be expected such income tested benefits would be higher at lower income levels, but for Ireland, Austria and the US benefits are rather constant and for the Netherlands the mean benefit value increases as income increases. In the case of Ireland and the US, benefits are clearly means-tested but generosity is not higher for the worst off. The pattern in the Netherlands does not correspond with formal eligibility rules; even though in some cases recipients are allowed to some other earnings these are not large amounts. ${ }^{18}$ There exist two possible (non-exclusive) explanations. Firstly, part of reported income may not be formal and are thus also not reported to the benefit agency. Secondly, part of other income is also derived from other income tested transfers such as housing allowance or income tested study grants for studying children. ${ }^{19} \mathrm{~A}$ general observation is that these benefits, by themselves, are insufficient to lift people out of absolute or relative poverty. However, with this type of benefits it is probably more appropriate to look at shorter spells than annual figures as the typical spell of benefit receipt may be shorter than a year.

\footnotetext{
${ }^{17}$ The UK is not discussed as the ECHP data do not include separate information on social assistance benefits in the UK.

${ }^{18}$ See for instance the website Recht op Algemene Bijstand.nl http://www.rechtopalgemenebijstand.nl/inhoud/index/pid/35\#geen (accessed May 2007, in Dutch only)

19 These transfers are included in the 'Other benefits' category but are not further discussed.
} 
Figure 5: Incidence of social assistance (below median income, 2000)
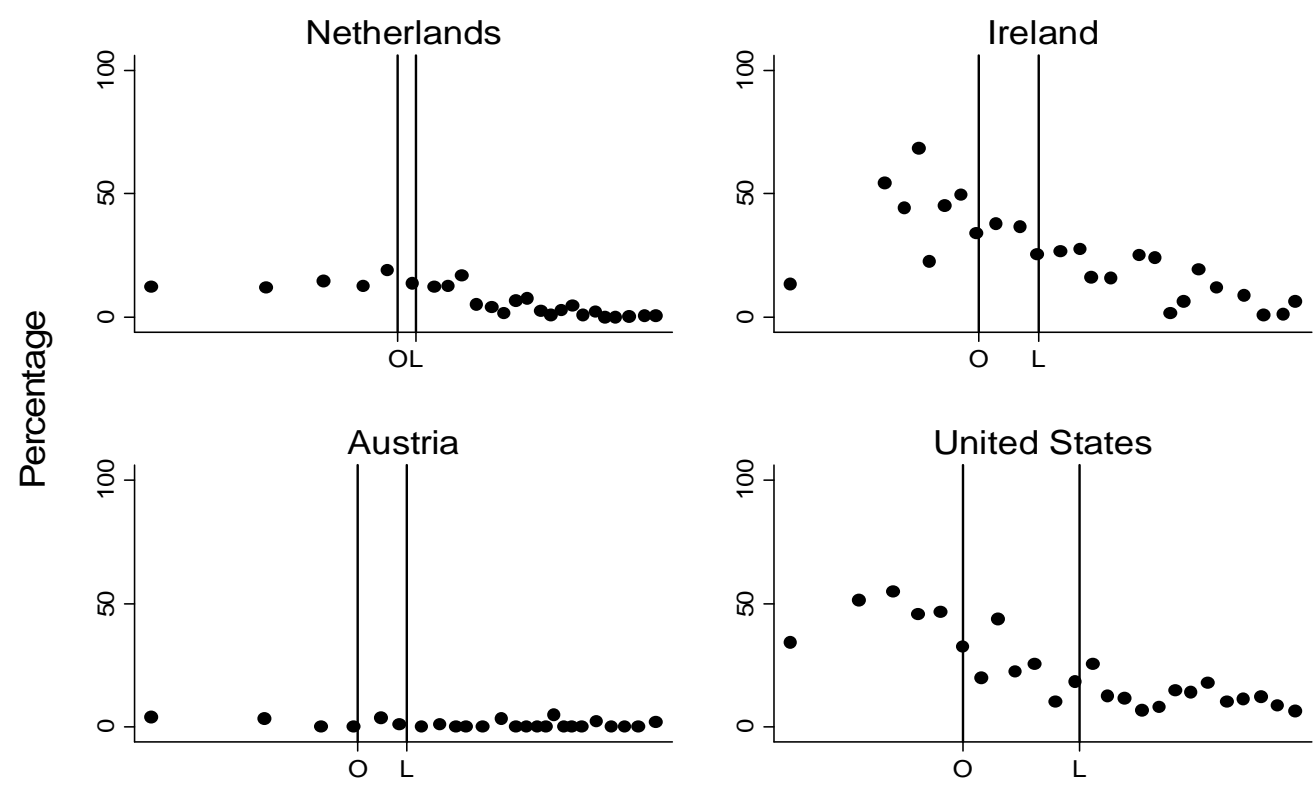

Equivalent income

Figure 6: Mean value of social assistance (below median income, 2000)

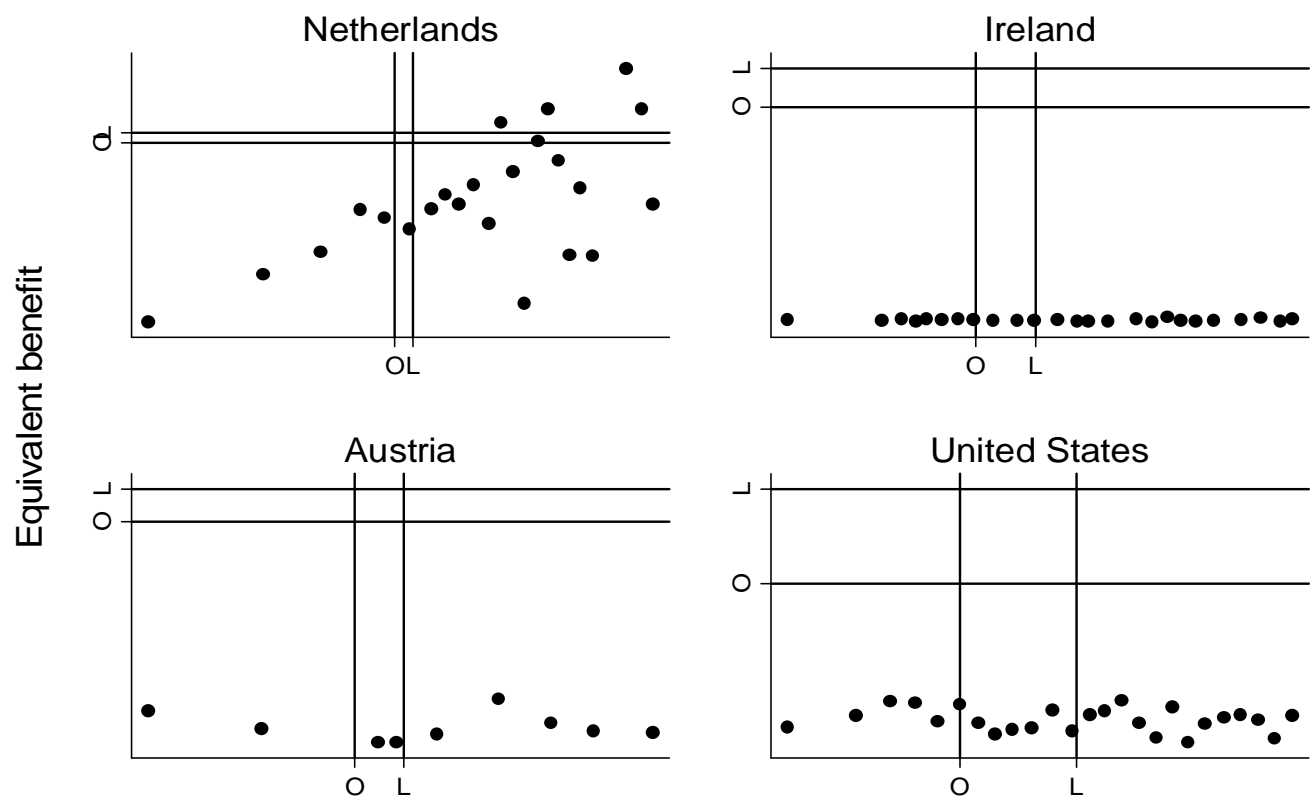

Equivalent income

Note: The figures include only observations below median income and all values are expressed in equivalent adult values (thus $50 \%$ of the total sample). Each dot represents the mean incidence or value (only including positive observations) of adult equivalent social assistance benefit received by $2 \%$ of the sample. The horizontal and vertical lines represent the adult equivalent Laeken (L) and Orshansky (O) poverty lines.

Source: Own calculations ECHP and CNEF-PSID 


\section{Absolute and relative poverty concepts and policy: discussion}

Using absolute Orshansky and relative Laeken poverty indicators on data from the EU member states (EU-15) and the USA showed significant differences between these partially overlapping groups of poor. We found not only differences between the size of absolute and relative poverty groups but also significant variations in terms of characteristics and we also showed how such differences would influence the selection of priority groups based on each poverty indicator. Moreover, this variation is not necessarily systematic across countries or across time. We further discussed how various types of social transfers affect absolute and relative poverty groups differently (in terms of benefit incidence and benefit level). In this concluding section we discuss the relevance of monitoring absolute and relative poverty indicators from a conceptual perspective.

Absolute and relative poverty indicators reflect related, but conceptually distinct, approaches to determining insufficient levels of well-being. They are related because absolute or relative concepts of poverty may be applied to the same welfare dimension (i.e. economic well-being) and measured by the same welfare indicator (i.e. income, expenditures or assets). They are conceptually distinct because the benchmark used to determine the cut-off separating well-being from ill-being either depends on the distribution of this welfare indicator (relative) or on some assessment of what constitutes a minimum achievement, basic need or right (absolute). This difference in approach has important implications. Take for instance a country or region where large parts of the population are facing an ongoing struggle to satisfy their basic needs in terms of food and shelter. If having just one or two sober meals a day is common in this society, absolute poverty exceeds relative poverty. Imagine that the $50^{\text {th }}$ percentile person in that society has two meals a day wile there is also a smaller group of persons having only one meal. Taking an internationally accepted standard of minimum food requirements or calorie intake as a benchmark, absolute (food) poverty rates may be well above $50 \%$ of the population. If, instead, one would use a relative poverty line where the middle person is taken as the benchmark, it is likely that only the persons having a single meal a day would be considered poor. The opposite situation may hold for a country in which the 
living standard is generally higher and perhaps some resources are being redistributed from the better off to the less well off; in such a country absolute poverty levels could be similar to relative poverty levels or considerably lower. ${ }^{20}$

'Not having enough to satisfy basic or main needs' or 'having much less than what is considered typical or normal in a given society' are distinct concepts of ill-being and their indicators may yield very different outcomes, especially over time. From a national policy perspective, it is therefore relevant to monitor both poverty concepts. Take for instance a steadily growing economy where the benefits from growth are equally distributed over the population; if one would only measure relative poverty one would 'miss' the fact that increasingly large parts of the population are able to afford a minimum basket of goods. If, instead, growth in this economy is unevenly distributed but nonetheless positive, a decrease in absolute poverty may be accompanied by increasing relative poverty. The groups of absolute and relative poor in a country partly overlap, but the degree of overlap changes over time. Thus, when designing or evaluating a policy, it makes sense to consider the potential impact that these policies may have on the absolute and relative poor. For the 'richer' countries (where absolute poverty is typically lower than relative poverty) a condition may be that only policies having a positive effect on absolute poverty reduction and a neutral effect on relative poverty will be given the consideration of actually being implemented. This is not to say that one should ignore other distributional effects, but from an equity perspective one might care more about those people having much less than what is considered minimal than those that have more.

Over time, the underlying composition of both poverty groups may change considerably, especially in fast growing economies or countries experiencing substantial social and demographic changes or structural reforms. As long as lower incomes profit at least a

\footnotetext{
${ }^{20}$ For some, this example illustrates the rationale for the argument that the use of relative poverty lines in poor regions or countries is nonsensical. We use this example because it illustrates that relative and absolute poverty statistics may yield very different outcomes. In addition, the example shows that there is a value judgement underlying every poverty concept of what is sufficient well-being or not and that the determination of a poverty line is always relative to some kind of benchmark (whether this is the society being studied or some global standard).
} 
little from economic growth in real terms, absolute poverty will typically decline. Trends in relative poverty rates depend on the distributional implications of economic growth, social and demographic change and government policies in a particular country; these factors not only affect the number of people living below the poverty line (i.e. changes in the shape of the income distribution at its lower end) but also affect the determination of the relative poverty line itself (i.e. changes in the middle section of the income distribution). Changes in overall poverty trends can thus mask larger (and opposing) welfare changes between socio-economic groups. For instance, if (minimum) pensions are annually adjusted for inflation while wages increase in tandem with real economic growth; working households experience an increase in purchasing power while pensioner households do not. Moreover, as working households are often also found in the middle of the income distribution, the relative poverty line rises with the real wage increase of the median household. As a result, absolute poverty under pensioners remains equal while absolute poverty under working households declines. However, relative poverty among pensioners will rise while it may or may not remain constant among working households. This is certainly relevant for the new EU member states but the distributional impact of ageing societies in the US and 'old' EU member states should also not be underestimated.

The Laeken indicators as used by the European Union do not inform us to what extent the extent the Italian or Dutch population has the resources to finance a minimum basket of goods. ${ }^{21}$ They only tell us that only $8 \%$ of the population in the Czech Republic is having an income that is lower than $60 \%$ of the income of the 'median' Czech (the Czech Republic has the lowest relative poverty level in the EU). ${ }^{22}$ Or take a country like Romania, with a relative poverty of $17 \%$ in 2000 ; it is very likely that an absolute poverty

\footnotetext{
${ }^{21}$ The Laeken indicators also include a relative poverty indicator which is 'anchored at a moment in time' (Atkinson et al., 2002). This means that the relative poverty line for a given year is updated to subsequent year using the rate of inflation. However, the anchoring of a relative poverty line over time is not an alternative for a minimum living standard indicator because the initial level of the poverty line is based on the income distribution and not on the costs of satisfying basic needs.

${ }^{22}$ These poverty statistics have been retrieved from the website of Eurostat, http://epp.eurostat.ec.europa.eu/portal/page?_pageid=1996,45323734\&_dad=portal\&_schema=PORTAL\& screen=welcomeref\&open $=/$ C/C5/C53\&language $=e n \&$ product=Yearlies_new_population\&root=Yearlies_ new_population\&scrollto=1068 (accessed March 2007).
} 
rate based on the minimum cost of living lies well above the current relative poverty rate. It is however, expected that the Romanian economy will continue to grow considerably, thereby reducing absolute poverty rates. Depending on how the benefits of this growth will be distributed across the population, relative poverty will increase, decline or remain constant. In the United States there is an ongoing debate over the problems associated with the Orshansky poverty indicator. As a result of this general dissatisfaction, the Bureau of Census also publishes alternative poverty statistics computed using various income definitions and another absolute poverty line which better reflects the current costs of basic needs but a relative poverty indicator is not part of such analyses (US Census Bureau, June 2005). Absolute and relative poverty statistics enable the identification and monitoring of distinct but partially overlapping groups. Each group reflects a vulnerable group in society and should be given special consideration. It therefore makes absolutely (!) sense to monitor progress using both relative and absolute poverty indicators. 


\section{References}

Atkinson, A. B., Cantillon, B., Marlier, E., \& Nolan, B. (2002). Social indicators: the EU and social inclusion. Oxford; New York: Oxford University Press.

International Social Security Association. (2002). Social security programmes throughout the world [Electronic Version]. Retrieved May 2007 from http://www.ssa.gov/policy/docs/progdesc/ssptw/.

International Social Security Association. (2003). Social security programmes throughout the world: The Americas 2003 [Electronic Version]. Retrieved April 2007 from http://www.ssa.gov/policy/docs/progdesc/ssptw/.

Marlier, E., Atkinson, A. B., Cantillon, B., \& Nolan, B. (2007). The EU and social inclusion: Facing the challenges. Bristol: The Policy Press.

Neubourg de, C., Castonguay, J., \& Roelen, K. (2007). Social safety nets and targeted social assistance: Lessons from the European experience. World Bank Social Protection working Papers, forthcoming, Washington DC, The World Bank

Notten, G., \& Neubourg de, C. (2007a). Poverty in Europe and the USA: Exchanging official measurement methods. MGSoG Working Paper, 2007/005, Maastricht Graduate School of Governance, Maastricht University, Maastricht.

Notten, G., \& Neubourg de, C. (2007b). Relative or absolute poverty in the US and EU? The battle of the rates. MGSoG Working Paper, 2007/001, Maastricht Graduate School of Governance, Maastricht University, Maastricht.

US Census Bureau. (June 2005). Alternative poverty estimates in the United States: 2003 [Electronic Version], US Department of Commerce, Economics and Statistics Administration, Washington D.C. Retrieved April 2007 from http://www.census.gov/prod/2005pubs/p60-227.pdf.

\section{Appendix: Official poverty in the EU and US: methodology and data}

The key difference between the US and EU official poverty measurement methods, is that the US method is based on an absolute poverty concept while the EU method is based on a relative poverty concept. The US poverty line was developed by Molly Orshansky in the 1960s and has been based on a low cost food plan for families under distress but also includes a non-food component. Being annually updated for inflation, the current US poverty line is essentially the same as the 1960 s poverty line. Although there is general agreement that the US poverty line is outdated because its monetary value is not based on a recent assessment of the minimum costs of living in US society, it is still being used simply because replacing it is politically not feasible. In Europe, and certainly at a European Union level, there is a tradition of using relative poverty lines especially in cross-national comparisons (Atkinson et al., 2002). Thus, when the fight against poverty 
and social exclusion also became an objective at the EU level after the Nice summit in December 2000, a relative poverty line was the (politically) preferred option to measure financial poverty.

The Laeken and Orshansky poverty measurement methods also differ in other aspects; the EU and US methods use different equivalence scales to adjust for differences in household size and demographic composition and even though both methods use income as the indicator of household welfare, the EU method uses disposable (after tax) income while the US method uses gross income. ${ }^{23}$

We apply both the Laeken and Orshansky poverty lines on nationally representative survey data from the United States and the old (EU-15) member states. The USA data come from the Panel Study on Income Dynamics (PSID) and for the European member states we use the European Community Household Panel (ECHP). Although for ease of display we largely focus on the years 1996 and 2001, we have information covering the period 1994-2001. Household annual disposable income is our welfare indicator. For the US we use the Cross National Equivalent Files (CNEF) version of the PSID because this dataset includes information on disposable income while the original PSID does not. The income variables in the ECHP are generally collected to provide an indication of household disposable income. In both datasets, the variable for total disposable income includes income from comparable sources such as wages, salaries, (entrepreneurial) earnings, other private income from transfers and capital as well as a range of social cash transfers. We use the resulting national (equivalent) income distributions in the data to derive the Laeken poverty lines for each country in each survey year. We converted the Orshansky poverty lines to the national price level of each European member state using 1993 Purchasing Power Indices. Subsequently we re-valued these poverty lines to later years using the national Consumer Price Indices. ${ }^{24}$ When analyzing the results, we

\footnotetext{
${ }^{23}$ See section Error! Reference source not found. in the appendix Poverty in Europe and the USA (Notten \& Neubourg de, 2007a) for a more elaborate discussion on the conceptual differences between both methods.

${ }^{24}$ See section Error! Reference source not found. in the appendix Poverty in Europe and the USA (Notten \& Neubourg de, 2007a) for a more elaborate discussion on the preparation of both datasets and the cross-national comparability of the poverty estimates.
} 
assume that the absolute poverty line indeed reflects the cost of a minimum basket of goods in each country. ${ }^{25}$

Because both datasets also include a panel component, we not only estimate the percentage of poor individuals in each country but are also able to provide estimates of long term poverty. To estimate long term poverty we follow the definition of the socalled 'At-persistent-risk-of-poverty' indicator as used by the European Union. Persons are considered long term poor if they are poor in the current period and they have been poor at least twice in the previous three year.

\footnotetext{
${ }^{25}$ This assumption is not crucial to the main objectives and arguments in our analysis as our absolute poverty indicator behaves in a similar manner as a minimum cost indicator. Nevertheless, it is likely that this assumption is violated (Notten \& Neubourg de, 2007b).
} 


\section{Maastricht Graduate School of Governance Working Paper Series}

\section{List of publications}

\begin{tabular}{lll}
$\begin{array}{l}\text { 2006 } \\
\text { No. }\end{array}$ & Author $(s)$ & Title \\
\hline 001 & $\begin{array}{l}\text { Gassmann, F. and } \\
\text { G. Notten }\end{array}$ & $\begin{array}{l}\text { Size matters: Poverty reduction effects of means-tested and } \\
\text { universal child benefits in Russia }\end{array}$ \\
\hline 002 & $\begin{array}{l}\text { Hagen-Zanker, J. } \\
\text { and } \\
\text { M.R. Muñiz Castillo }\end{array}$ & $\begin{array}{l}\text { Exploring multi-dimensional wellbeing and remittances in } \\
\text { El Salvador }\end{array}$ \\
\hline 003 & Augsburg, B. & $\begin{array}{l}\text { Econometric evaluation of the SEWA Bank in India: } \\
\text { Applying matching techniques based on the propensity } \\
\text { score }\end{array}$ \\
\hline 004 & Notten, G. and & Poverty and consumption smoothing in Russia \\
& D. de Crombrugghe ( & \\
\hline
\end{tabular}

\section{7}

\begin{tabular}{|c|c|c|}
\hline No. & Author(s) & Title \\
\hline 001 & $\begin{array}{l}\text { Notten, G. and C. de } \\
\text { Neubourg }\end{array}$ & $\begin{array}{l}\text { Relative or absolute poverty in the US and EU? The battle } \\
\text { of the rates }\end{array}$ \\
\hline 002 & $\begin{array}{l}\text { Hodges, A. A. } \\
\text { Dufay, K. Dashdorj, } \\
\text { K.Y. Jong, T. } \\
\text { Mungun and U. } \\
\text { Budragchaa }\end{array}$ & $\begin{array}{l}\text { Child benefits and poverty reduction: Evidence from } \\
\text { Mongolia's Child Money Programme }\end{array}$ \\
\hline 003 & $\begin{array}{l}\text { Hagen-Zanker, J. } \\
\text { and Siegel, M. }\end{array}$ & The determinants of remittances: A review of the literature \\
\hline 004 & Notten, G. & $\begin{array}{l}\text { Managing risks: What Russian households do to smooth } \\
\text { consumption }\end{array}$ \\
\hline 005 & $\begin{array}{l}\text { Notten, G. and C. de } \\
\text { Neubourg }\end{array}$ & $\begin{array}{l}\text { Poverty in Europe and the USA: Exchanging official } \\
\text { measurement methods }\end{array}$ \\
\hline 006 & $\begin{array}{l}\text { Notten, G and C. de } \\
\text { Neubourg }\end{array}$ & $\begin{array}{l}\text { The policy relevance of absolute and relative poverty } \\
\text { headcounts: Whats in a number? }\end{array}$ \\
\hline 007 & $\begin{array}{l}\text { Hagen-Zanker, J. } \\
\text { and M. Siegel }\end{array}$ & $\begin{array}{l}\text { A critical discussion of the motivation to remit in Albania } \\
\text { and Moldova }\end{array}$ \\
\hline 008 & Wu, Treena & $\begin{array}{l}\text { Types of Households most vulnerable to physical and } \\
\text { economic threats: Case studies in Aceh after the Tsunami } \\
\text { (Theme 2) }\end{array}$ \\
\hline
\end{tabular}

